\section{Detecção do Virrus Epstein-Barr em Tonsilites Recorrentes}

\author{
Eliane Pedra Dias ${ }^{1}$, Monica Lage da Rocha ${ }^{2}$, Maria \\ Odete de Oliveira Carvalbo ${ }^{3}$, Lidia Maria da Fonte \\ de Amorim
}

Resumo / Summary

\section{Detection of Epstein-Barr virus in recurrent tonsillitis}

Palavras-chave: imuno-histoquímica, infecções por vírus epstein-barr, pcr, tonsilite.

Keywords: immunohistochemistry, epstein-barr virus infection, pcr, tonsillitis.

\begin{abstract}
A Eventos considerados na predisposição e causa incluem a utilização errônea de antibióticos em crises agudas, alterações da microflora, mudanças estruturais nas criptas epiteliais tonsilares e infecções virais. A infecção pelo vírus EpsteinBarr (EBV) ocorre freqüentemente na infância persistindo em linfócitos de tonsilas, podendo causar tonsilites recorrentes. Pouco se conhece sobre a persistência e reativação do EBV em pacientes imunocompetentes. Alguns métodos como a hibridização in situ, a reação em cadeia da polimerase (PCR) e a imuno-histoquímica têm sido utilizados no estudo da patogenia do vírus. Objetivo: Para caracterizar a associação do vírus Epstein-Barr com tonsilites recorrentes examinamos a presença do EBV pela PCR e por imuno-histoquímica usando como alvo a proteína viral LMP-1. Forma de Estudo: Estudo transversal com análise de prevalência amostral. Material e Métodos: Foram selecionados 24 blocos parafinados de tonsilas, provenientes do Serviço de Anatomia Patológica, removidas de crianças de 2 a 12 anos com diagnóstico de tonsilite recorrente. Resultados: O genoma do EBV foi detectado em $13(54,1 \%)$ e a LMP-1 em $9(37,5 \%)$ dos casos. Conclusão: As tonsilas das crianças podem ser colonizadas pelo EBV e este pode estar associado à patogenia das tonsilites recorrentes.
\end{abstract}

\begin{abstract}
$R$ ecurrent tonsillitis has been the subject of frequent investigation. Misuse of antibiotic therapy in acute tonsillitis, changes to the tonsillar microflora, structural changes to the tonsillar crypts, and viral infections have been listed as predisposing or causal factors for recurrent tonsillitis. Epstein-Barr virus (EBV) infection usually occurs in early childhood and may persist in tonsillar lymphocytes, thus leading to the onset of recurrent tonsillitis. Little is known about the persistence and reactivation of EBV strains in immunocompetent patients. Methods such as in situ hybridization, polymerase chain reaction (PCR), and immunochemistry have been used to study the pathogenesis of the EBV. Aim: this study aims to characterize the association between EBV and recurrent tonsillitis by investigating the presence of EBV through PCR and immunohistochemistry, using viral protein LMP-1 as a target. Study design: this is a cross-sectional study with analysis of sample prevalence. Materials and method: twenty-four paraffin-embedded tonsil specimens from the Pathology Service were selected. The specimens were removed from children aged between 2 and 12 years diagnosed with recurrent tonsillitis. Results: EBV genome was detected in 13 (54.1\%) specimens, whereas viral protein LMP-1 was found in 9 (37.5\%) specimens. Conclusion: children's tonsils can be colonized by EBV and such colonies may be associated with the pathogenesis of recurrent tonsillitis.
\end{abstract}

\footnotetext{
${ }^{1}$ Doutora em Patologia, Professora Titular do Departamento Patologia da Faculdade de Medicina, Patologista do Serviço de Anatomia Patológica do Hospital Universitário Antonio Pedro, Coordenadora do Programa de Pós- Graduação em Patologia - Universidade Federal Fluminense.

${ }^{2}$ Mestre em Patologia - UFF, Cirurgiã- dentista, Doutoranda do Programa em Pós-Graduação em Patologia- área de concentração Patologia bucodental da Universidade Federal Fluminense.

${ }^{3}$ Mestre em Patologia, Bióloga.

${ }^{4}$ Doutora em Biologia, Professora Adjunto do Departamento de Biologia Celular e Molecular do Instituto de Biologia da Universidade Federal Fluminense. Pós-Graduação em Patologia Hospital Universitário Antonio Pedro Universidade Federal Fluminense.

Endereço para correspondência: Monica Lage da Rocha Rua das Laranjeiras 154 ap. 505 bloco 2 Laranjeiras RJ $22240-003$.

Este artigo foi submetido no SGP (Sistema de Gestão de Publicações) da RBORL em 18 de junho de 2007. cod.4615

Artigo aceito em 22 de setembro de 2007.
} 


\section{INTRODUÇÃO}

O anel linfático de Waldeyer faz parte da primeira linha de defesa contra patógenos por estar localizado na porta de entrada das vias aérea e digestiva. É constituído por tecido linfóide, dos quais fazem parte as tonsilas palatinas e faríngeas. Vários microorganismos podem infectar estes tecidos e causar tonsilites, sendo mais freqüentes as de origem bacteriana. ${ }^{1}$ Ainda não está bem entendido o mecanismo pelo qual algumas crianças desenvolvem tonsilites recorrentes e nem a causa do aumento exagerado das tonsilas. Várias hipóteses têm sido propostas, tais como a possivel resistência de microorganismos a antibioticoterapia e a interferência do streptococcus $\alpha$ atuando como protetor da orofaringe contra streptococcus $\beta$, deste modo prevenindo as tonsilites recorrentes. Alguns estudos têm sugerido que infecções virais poderiam estar envolvidas nas infecções recorrentes, entre estes o vírus Epstein-Barr (EBV) e o herpes simples. ${ }^{2-4}$

O EBV foi descoberto em 1964, em cultura de células obtidas de Linfoma de Burkitt e, em 1968, foi demonstrado que era o agente etiológico da mononucleose infecciosa. ${ }^{5} E ́$ um herpesviridae da subfamília do gamaherpesvirinae que infecta a maioria dos indivíduos antes da idade adulta. $\mathrm{Na}$ primeira infecção, o vírus é transmitido pela saliva e invade as células epiteliais da orofaringe, que são destruídas, infectando em seguida linfócitos B circulantes, nos quais entra em estado de latência. ${ }^{4} \mathrm{O}$ genoma do EBV consiste de uma molécula de DNA linear de 172 quilobases que codifica aproximadamente 100 proteínas virais, no entanto, apenas 10 genes são expressos in vitro nas células B infectadas (latência): seis proteínas nucleares, EBNAs 1, 2, 3A, 3B, 3C e EBNA-LP, além de duas proteínas de membrana, LMP-1 e LMP-2 e dois RNAs pequenos, EBER 1 e EBER 2.6 A proteína do antígeno nuclear 1 (EBNA-1) liga-se ao DNA viral fazendo com que o genoma do vírus permaneça na célula infectada como um epissomo circular e a expressão da LMP-1 em indivíduos imunodeprimidos pode induzir a transformação de linfócitos B e o surgimento de processos linfoproliferativos. ${ }^{6}$

Em contraste com estudos realizados in vitro, ainda não se estabeleceu in vivo, o local da replicação do EBV. A mononucleose infecciosa e a leucoplasia pilosa oral são utilizados como modelos para estudo do mecanismo de replicação do vírus. ${ }^{3}$ Ainda parece incerto como se estabelece a replicação do EBV em indivíduos saudáveis. As tonsilas parecem ser candidatas para o sítio de replicação do EBV. 7,8 No estudo realizado por Babcock (1998), foram detectadas formas epissomais lineares do DNA do EBV em linfócitos tonsilares. A presença de formas lineares pode indicar que o DNA viral está replicando nos linfócitos de tonsilas, em indivíduos saudáveis e infectados previamente pelo EBV. Até pouco tempo acreditava-se que o vírus era capaz de infectar apenas linfócitos B e células epiteliais, porém já existem relatos de infecção em linfócitos T normais. ${ }^{3}$

Além da mononucleose infecciosa, o EBV está associado a outras doenças benignas como a leucoplasia pilosa oral e malignas como linfomas de Hodgkin, linfomas não Hodgkin de células B e T, carcinomas nasofaríngeos, gástricos e mamários. Atualmente está sendo correlacionado a doenças auto-imunes como lúpus eritematoso e esclerose múltipla. ${ }^{5,9}$

Diversas técnicas moleculares estão sendo utilizadas para a demonstração da presença do vírus EBV, como por exemplo, a reação em cadeia da polimerase (PCR) e a hibridização in situ (IHS).A PCR permite a detecção de quantidades mínimas de DNA viral em esfregaços e tecidos. Segundo PEIPER (1990), a amplificação de seqüências específicas do genoma do EBV pela PCR é um método de identificação do DNA viral rápido, sensível e com boa especificidade. Além disso, permite a utilização de biópsias que foram parafinadas e mantidas em arquivos possibilitando estudos retrospectivos.

O objetivo deste estudo foi investigar a associação do vírus Epstein-Barr com tonsilites recorrentes, através da identificação do genoma do vírus pela PCR e da proteína LMP-1 pela imuno-histoquímica.

\section{MATERIAL E MÉTODOS}

Realizou-se um estudo transversal, de análise da prevalência da infecção pelo EBV em produtos de tonsilectomias, cuja indicação foi a recorrência e o aumento importante do volume. O projeto foi aprovado no Comitê de Ética em Pesquisa da Faculdade de Medicina (CEPCMM), sob o $n^{\circ} 077 / 06$. Entre as tonsilectomias analisadas no Serviço de Anatomia Patológica no período de 1999 a 2006, foram selecionadas as lâminas daquelas com diagnóstico de tonsilite crônica hipertrófica. Após a exclusão dos casos inadequados (material insuficiente, artefatos técnicos, fixação inadequada), restaram para estudo 24 blocos parafinados com fragmentos de tonsilas fixadas em formol tamponado a $10 \%$.

A identificação da presença do DNA viral foi realizada através da reação de Nested PCR utilizando DNA extraído a partir de três fatias do tecido com $5 \mu \mathrm{m}$ de espessura. Ao cortar cada amostra o micrótomo era limpo e as navalhas histológicas trocadas. Para a extração do DNA, as amostras foram desparafinizadas com três banhos de xileno aquecido a $65^{\circ} \mathrm{C}$ e hidratadas com banhos sucessivos de álcool a 100, 95 e 70\%. Após centrifugação, o tecido foi ressuspendido em $220 \mu \mathrm{L}$ de água Milli-Q autoclavada e digerido a $56^{\circ} \mathrm{C}$ em presença de $30 \mu \mathrm{l}$ de SDS a $10 \%, 6 \mu \mathrm{L}$ de proteinase $\mathrm{K}$ a $25 \mathrm{mg} \%$. A cada dia era adicionada proteinase $\mathrm{K}$ até que as amostras estivessem completamente digeridas. A suspensão foi extraída com fenol: clorofórmio: álcool isoamílico (25:24:1) para a retirada das proteínas não digeridas e, após a precipitação do DNA com $35 \mu \mathrm{L}$ de acetato de sódio (3M) e $1 \mathrm{~mL}$ de etanol absoluto, as 
amostras foram centrifugadas e ressuspendidas com $50 \mu \mathrm{L}$ de água Milli-Q estéril. ${ }^{11}$ A qualidade e uma estimativa da quantidade do DNA genômico extraído foi verificada por eletroforese em gel de agarose a 1,7\% contendo brometo de etídio. Os DNAs genômicos de todas as amostras foram submetidos a PCR para o gene da beta-globina (gene celular constitutivo) para verificar se as amostras obtidas possuíam DNA amplificável. A reação da Nested PCR para amplificar o gene EBNA-1 foi utilizada na identificação da presença do DNA do EBV gerando, na primeira reação, um fragmento de $279 \mathrm{pb}$ e na segunda reação, um fragmento de 209pb. ${ }^{12}$ Na primeira reação, que detecta herpes vírus, o mix da reação continha 2,5 $\mathrm{ll}$ de DNA de cada amostra extraída, 0,5 $\mu$ l dos primers a $50 \mu \mathrm{M}$ (5'AAG-GAG-GGTGGT-TTG-GAA-AG 3' e 5'AGA-CAA-TGG-ACT-CCC-TTAGC 3'), 2,5 $\mu$ l de tampão (10mM TrisHCL pH8.3, 50mM de KCL), $0,75 \mu l$ de $\mathrm{MgCl}$ a $2 \mathrm{mM}, 2 \mu \mathrm{ldNTP}$ a $2 \mathrm{mM}$ e $0,2 \mu l$ de Taq polimerase Invitrogen $(5 \mathrm{U} / \mu \mathrm{l})$ e quantidade de água Milli-Q suficiente para completar $25 \mu \mathrm{l}$ de volume final. O DNA utilizado como controle positivo foi extraído da linhagem celular B9507, infectada por vírus EBV, já o controle negativo foi realizado com água Milli-Q estéril. As amplificações foram realizadas utilizando a seguinte programação: 2 min. a $94^{\circ} \mathrm{C}$, seguida por 35 ciclos de 30 seg. a $94^{\circ} \mathrm{C}, 30 \mathrm{seg}$. a $55^{\circ} \mathrm{C}$ e $30 \mathrm{seg}$. a $72^{\circ} \mathrm{C}$ seguido de extensão final de 10 min. a $72^{\circ} \mathrm{C}$. Para a segunda reação, os primers específicos para o EBV (5' ATC-GTG-GTC-AAGGAG-GTT-CC 3' e 5' ACT-CAA-TGG-TGT-AAG-ACG-AC 3'), foram utilizados com as condições da reação anterior utilizando a seguinte programação: $45 \mathrm{seg}$. a $94^{\circ} \mathrm{C}$, seguida por 35 ciclos de $20 \mathrm{seg}$. a $94^{\circ} \mathrm{C}, 30 \mathrm{seg}$. a $55^{\circ} \mathrm{C}, 30 \mathrm{seg}$. a $72^{\circ} \mathrm{C}$ seguido de extensão final de $10 \mathrm{~min}$. a $72^{\circ} \mathrm{C}$. A identificação da amplificação gênica foi realizada através de um gel de agarose a 1,7\% corado com brometo de etídio, onde $7 \mu$ de cada produto do Nested PCR foi separado por eletroforese, utilizando como parâmetro um peso molecular de $100 \mathrm{pb}$ (Fermentas).

Para investigar a presença da proteína de latência LMP-1, os blocos parafinados foram submetidos à microtomia e cortes com $5 \mu \mathrm{m}$ de espessura foram depositados em lâminas pré-tratadas com adesivo (Silano ${ }^{\circledR 4} \%$ ), seguiu-se a desparafinização e lavagem com tampão tris salina. As lâminas foram submetidas ao tratamento para recuperação antigênica por 30 minutos em banho-maria a $96^{\circ} \mathrm{C} \mathrm{com}$ tampão citrato. $\mathrm{O}$ anticorpo primário foi o monoclonal antiLMP-1 (DAKO®) diluído 1:400 conforme especificação do fabricante e o Kit LSAB (DAKO $\left.{ }^{\circledR}\right)$ contendo o anticorpo secundário biotinilado e o conjugado de Streptavidina e peroxidase. A revelação foi realizada através da solução cromógena (Kit DAB-DAKO®) e a contra-coloração realizada com hematoxilina de Harris. Cortes de linfoma e hiperplasia fibrosa inflamatória foram utilizados como controle positivo e negativo respectivamente.

\section{RESULTADOS}

A amostra utilizada neste estudo foi proveniente de pacientes pediátricos de 2 a 12 anos, com média de 7,4 anos (desvio padrão de 3,1 anos), sendo 15 (62,5\%) do sexo feminino e $9(37,5 \%)$ do sexo masculino. A tonsilectomia foi indicada por hipertrofia de amígdalas e vegetações adenóides (HAVA) em 17 casos, por HAVA e tonsilite recorrente em cinco e tonsilite recorrente em dois casos.

O DNA genômico visualizado no gel de agarose mostrou boa quantidade de DNA nas amostras extraídas. Das 24 tonsilas submetidas à PCR, detectou-se em 16 $(66,7 \%)$ a amplificação do gene da beta-globina (Figura 1). Destas, $10(62,5 \%)$ amplificaram para o genoma do EBV (Tabela 1). O DNA-EBV foi detectado em 13 (54,1\%) das 24 tonsilas (Figura 2), dentre os quais 10 casos eram provenientes de pacientes do sexo feminino $(66,7 \%$ de 15 mulheres) e 10 casos eram de pacientes que representavam $58,8 \%$ daqueles que tinham de 6 e 12 anos (Tabela 2). A investigação da proteína de latência LMP-1 nas 24 tonsilas revelou imunorreatividade em poucos linfócitos de $9(37,5 \%)$ tonsilas (Figura 3).

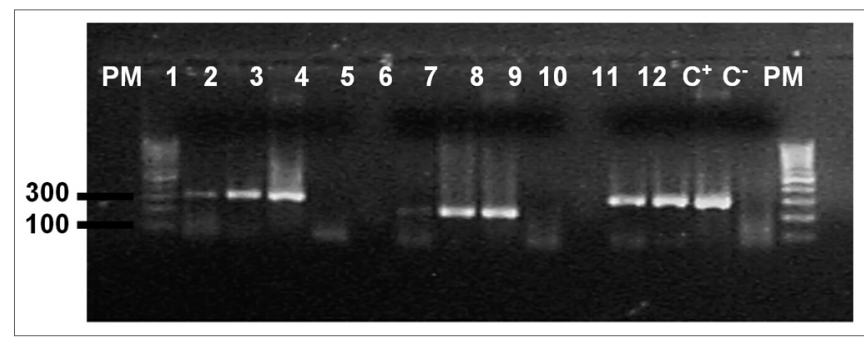

Figura 1. Eletroforese em gel de agarose a 1,7\% mostrando a amplificação do gene $\beta$-globina, (268pb) PM - Peso molecular 100pb, Amostras 1 - 12, C+ - DNA extraído da linhagem B9507, C- - água Milli-Q.

Tabela 1. Amplificação do gene beta-globina e genoma do EBV nas tonsilas avaliadas.

\begin{tabular}{cccc}
\hline & Tonsilas & EBV + & EBV - \\
\hline Bglobina + & 16 & $10(62,5 \%)$ & $6(37,5 \%)$ \\
Bglobina - & 8 & $3(37,5 \%)$ & $5(62,5 \%)$ \\
\hline TOTAL & 24 & $13(54 \%)$ & $11(46 \%)$ \\
\hline
\end{tabular}

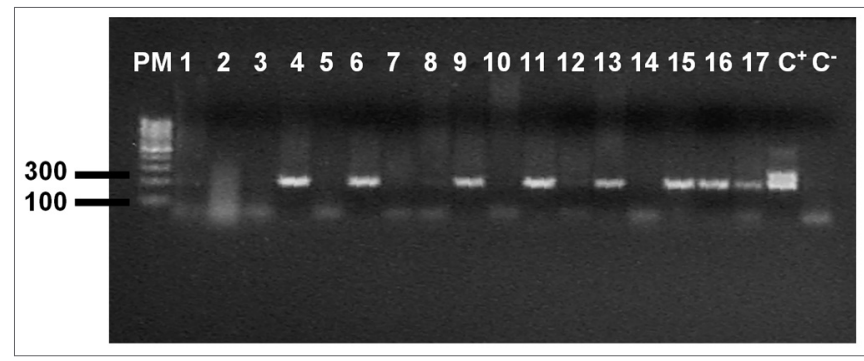

Figura 2. Eletroforese em gel de agarose a 1,7\% mostrando a amplificação do genoma de EBV, (209pb) PM - Peso molecular 100pb, Amostras 1 - 17, C+ - DNA extraído da linhagem B9507, C- - água Milli-Q. 
Tabela 2. Distribuição das 24 tonsilas investigadas segundo sexo e idade dos pacientes, indicação da tonsilectomia, diagnóstico histopatológico e positividade para o DNAEBV e proteína LMP-1.

\begin{tabular}{|c|c|c|c|c|c|c|}
\hline $\mathrm{N}^{\circ}$ & Sexo & Id & Indicação da Tonsilectomia & Diagnóstico histopatológicos & PCR & LMP-1 \\
\hline 1 & M & 10 & HAVA & Tonsilite crônica hipertrófica & - & - \\
\hline 2 & $\mathrm{~F}$ & 6 & HAVA & Tonsilite crônica hipertrófica & - & - \\
\hline 3 & $\mathrm{~F}$ & 9 & HAVA e Tonsilite de repetição & Tonsilite crônica hipertrófica & + & + \\
\hline 4 & M & 4 & HAVA & Tonsilite crônica hipertrófica & - & - \\
\hline 5 & M & 6 & HAVA & Tonsilite crônica hipertrófica & + & + \\
\hline 6 & $\mathrm{~F}$ & 7 & HAVA e Tonsilite de repetição & Tonsilite crônica hipertrófica & + & + \\
\hline 7 & M & 6 & Tonsilite de repetição & Tonsilite crônica hipertrófica & - & - \\
\hline 8 & M & 10 & HAVA & Tonsilite crônica hipertrófica & + & + \\
\hline 9 & $\mathrm{~F}$ & 9 & HAVA & Tonsilite crônica hipertrófica & + & - \\
\hline 10 & $\mathrm{~F}$ & 12 & HAVA & Tonsilite crônica hipertrófica & + & - \\
\hline 11 & M & 6 & HAVA e Tonsilite de repetição & Tonsilite crônica hipertrófica & - & - \\
\hline 12 & $\mathrm{~F}$ & 12 & HAVA e Tonsilite de repetição & Tonsilite crônica hipertrófica & - & - \\
\hline 13 & M & 5 & HAVA & Tonsilite crônica hipertrófica & - & - \\
\hline 14 & M & 5 & Tonsilite de repetição & Tonsilite crônica hipertrófica & + & - \\
\hline 15 & $\mathrm{~F}$ & 12 & HAVA & Tonsilite crônica hipertrófica & - & - \\
\hline 16 & $\mathrm{~F}$ & 8 & HAVA & Tonsilite crônica hipertrófica & - & - \\
\hline 17 & $\mathrm{~F}$ & 6 & HAVA & Tonsilite crônica hipertrófica & + & + \\
\hline 18 & M & 3 & HAVA & Tonsilite crônica hipertrófica & - & - \\
\hline 19 & $\mathrm{~F}$ & 4 & HAVA e Tonsilite de repetição & Tonsilite crônica hipertrófica & + & - \\
\hline 20 & $\mathrm{~F}$ & 12 & HAVA & Tonsilite crônica hipertrófica & + & + \\
\hline 21 & $\mathrm{~F}$ & 10 & HAVA & Tonsilite crônica hipertrófica & + & + \\
\hline 22 & $\mathrm{~F}$ & 2 & HAVA & Tonsilite crônica hipertrófica & + & + \\
\hline 23 & $\mathrm{~F}$ & 4 & HAVA & Tonsilite crônica hipertrófica & - & - \\
\hline 24 & $\mathrm{~F}$ & 10 & HAVA & Tonsilite crônica hipertrófica & + & + \\
\hline
\end{tabular}

№ = Número do caso HAVA=hipertrofia de amígdalas e vegetações adenóides + positivo - negativo

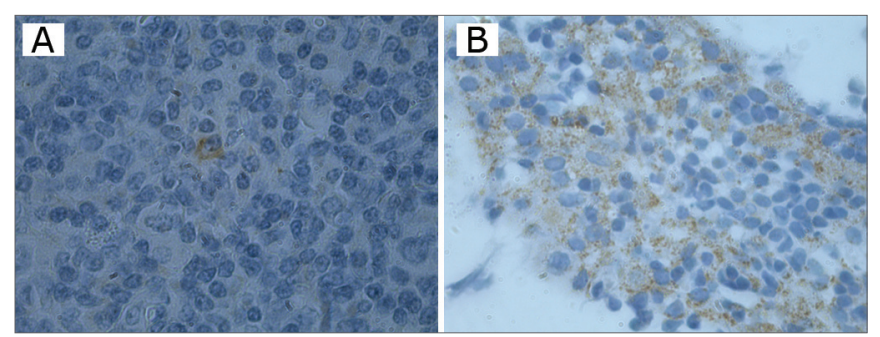

Figura 3. Imuno-histoquímica mostrando positividade para LMP-1 nos casos A e B (1000X).

\section{DISCUSSÃO}

O vírus Epstein-Barr é o agente causador da mononucleose infecciosa e da leucoplasia pilosa oral, sendo ainda associado a várias neoplasias malignas incluindo a doença de Hodgkin, linfomas B e T, carcinomas nasofaríngeos e carcinomas gástricos de pacientes imunossuprimidos. No entanto, pouco se conhece sobre a patogenia do vírus em pacientes imunocompetentes. A hipótese das tonsilas representarem um possível sítio de replicação do vírus tem sido proposta por vários pesquisadores ${ }^{2,3,8,13}$.

As técnicas moleculares têm sido muito utilizadas para o diagnóstico e monitoramento de pacientes com doenças virais e a identificação do DNA-EBV pode ser feita através da hibridização in situ (ISH) e da reação em cadeia da polimerase (PCR), sendo consideradas, por alguns autores, igualmente sensíveis na detecção do EBV. ${ }^{14}$ Além disso, proteínas virais encontradas na infecção latente e replicativa podem ser identificadas através da imunohistoquímica. ${ }^{2-4,13}$ As tonsilas são consideradas sítios da infecção inicial, de persistência e replicação viral e o EBV pode infectar as tonsilas de crianças e estar envolvido no desenvolvimento das tonsilites recorrentes. ${ }^{2,15,16}$

Em nosso estudo selecionamos tonsilas de crianças com idade média de 7,4 anos e diagnóstico de tonsilites crônicas e hipertróficas. Acreditamos que o grande número de infecções recorrentes em tonsilas na infância pode estar 
associado ao vírus Epstein-Barr, cujo contato inicial ocorre, freqüentemente, em torno dos sete anos. Das 24 tonsilas investigadas, 16 tiveram a amplificação positiva para bglobina, comprovando a presença de DNA constitucional no material extraído e que este DNA era amplificável. Destas 16, em 10 obteve-se a amplificação do EBV, bem como em três tonsilas negativas para b-globina, indicando que, embora o DNA-EBV tenha sido amplificado nestas três amostras, não podemos afirmar que nas cinco outras negativas para EBV não amplificaram pela ausência do vírus ou pela baixa quantidade ou qualidade do DNA. Pode-se afirmar que $54,1 \%$ das tonsilas investigadas estavam infectadas pelo EBV, mas o mapeamento desta infecção, o que possibilitaria a identificação da população celular alvo, é um limite técnico. Niedobitek et al. ${ }^{17}$, utilizando a ISH para estabelecer o padrão e distribuição de linfoblastos EBV positivos, que foram encontrados principalmente em áreas extrafoliculares. A prevalência da infecção pelo EBV em tonsilites é variável de acordo com o método de detecção. Estudos com ISH para detecção de EBER identificaram $26 \% \%^{19}, 29 \% \%^{2}$ e65\% $\%^{4}$ de associação do EBV com tonsilite; já para os que utilizaram a PCR, indicam uma prevalência de até $65 \%\left(11 \%^{20}, 58 \% \%^{15}, 64 \%^{17}\right)$. Assim, a PCR confirma a sua maior sensibilidade na detecção molecular e indica uma associação do EBV com as tonsilites.

Os resultados de Ping-Ching Pai et al. ${ }^{15}$, obtidos por Nested-PCR, ao investigarem a associação do EBV com 57 tonsilites e 31 tonsilas com neoplasia maligna (respectivamente $58 \%$ e $51 \%$ ) indicam que a associação não se restringe às tonsilites recorrentes.

Ikeda et al. $^{3}$ (2000) utilizaram a ISH, RT-PCR e imuno-histoquímica em 15 fragmentos de tonsilas provenientes de pacientes com tonsilite crônica. Numa detalhada investigação, demonstraram que linfócitos tonsilares constituem não só um reservatório como ambiente de replicação do EBV. Nossos resultados, de modo semelhante, identificaram a LMP-1, proteína de latência do EBV, em $37,5 \%$ das tonsilas investigadas, demonstrando que a imuno-histoquímica pode ser um método de investigação inicial da infecção latente pelo EBV. Ainda existem na patogenia da infecção pelo EBV, diversas questões a serem investigadas, sendo particularmente desafiante a sua associação com as tonsilas.

\section{CONCLUSÃO}

A identificação de uma alta $(54,1 \%)$ prevalência de DNA-EBV e a identificação de LMP-1 (37,5\%) em tonsilites recorrentes em crianças, indicam as tonsilas como reservatório do EBV e que este pode estar envolvido em infecções recorrentes. Muitos aspectos da infecção latente e replicativa do vírus Epstein-Barr permanecem obscuros, constituindo-se possíveis focos de futuras investigações.

\section{REFERÊNCIAS BIBLIOGRÁFICAS}

1. Ciceran A. Manual Boca e Faringe. www.iapo.org. 2004; 84-94.

2. Endo LH, Ferreira D, Montenegro MC, Pinto GA, Altemani A, Bortoleto AE et al. Detection of Epstein-barr virus in tonsillar tissue of children and the relationship with recurrent tonsillitis. Int J Pediatr Otorhinolaryngol 2001;58:9-15.

3. Ikeda T, Kobayashi R, Horiuchi M, Nagata Y, Hasegawa M Mizuno F et al. Detection of lymphocytes productively infected with EpsteinBarr virus in non- neoplastic tonsils. J Gen Virol 2000;81:1211-6.

4. Chagas AC, Endo LH, Santos WLC, Pinto GA, Sakano E, Brousset P et al. Is there a relationship between the detection of human herpesvirus 8 and Epstein-Barr virus in Waldeyers ring tissues? Int J Pediatr Otorhinolaryngol 2006:1923-7.

5. Ribeiro-Silva AR, Zucoloto S. O papel do vírus Epstein-Barr na tumorigênese humana. Medicina Ribeirão Preto 2003;36:16-23.

6. Cruchley AT, William DM. Epstein-barr virus: biology and disease. Oral Dis Suppl 1 1997;5156-63.

7. Babcock GJ, Decker LL, Volk M, Lawson TD. EBV Persistence in Memory Cells In Vivo. Immunity 1998;9:395-404.

8. Kobayashi R, Takeuchi H, Sasaki M, Hasegawa M, Hirai K. Detection of Epstein-Barr virus infection in the epithelial cells and lymphocytes of non-neoplastic tonsils by in situ hybridization and in situ PCR. Arch Virol 1998;143:803-13.

9. Lawrense SY, Rickinson AB. Epstein-Barr: 40 years on. Nature Review/ Cancer 2004;4 Oct:757-68.

10. Peiper SC et al. Detection of Epstein-Barr virus genomes in arquival tissues by polimerase chain reaction. Arch Pathol LabMed 1990;114:711-4.

11. Chan PKS, Chan DPC, To KF, Yu MY, Cheung JLK, Cheng AF. Evaluation of extraction methods from paraffin wax embebed tissues for PCR amplification of human and viral DNA. J Clin Pathol 2001;54:401-3.

12. Cinque $\mathrm{P}$, Brytting $\mathrm{M}$, Vago L, Castagna A, Parravicini C, Zanchetta $\mathrm{N}$ et al. Epstein-barr vírus DNA in cerebrospinal fluid from patients with AIDS- related primary lymphoma of the central nervous system. Lancet 1993;342:398-401.

13. Hudnall SD, Ge Y, Wei L, Yang NP, Wang HQ and Chen T. Distribution and phenotype of Epstein-Barr virus-infected cells in human pharyngeal tonsils. Mod Pathol 2005;18:519-527.

14. Gulley ML. Molecular diagnosis of Epstein-Barr virus-related diseases. JMD 2001;3(1):1-10.

15. Pai PC et al. Prevalence of LMP-1 gene in tonsils and non-neoplastic nasopharynxes by Nested- Polimerase Chain Reaction in Taiwan. Head \& Neck 2004:619-24.

16. Yamanaka N, Kataura A. Viral infection associated with recurrent tonsillitis. Acta Otolaryngol (Stocckh) 1984;416 (Suppl.):30-7.

17. Niedobitek G, Herbst H, Young LS, Brooks L, Masucci MG, Crocker $\mathrm{J}$ et al. Patterns of Epstein-Barr virus infection in non-neoplastic lymphoid tissue. Blood 1992;79(10):2520-6.

18. Kunimoto M, Tamura S, Yoshie O, Tabata T. Epstein-Barr virus in Waldeyer lymphatic tissue. Adv Otorhinolaryngol Basel Karger 1992; 47:151-60.

19. Yoda K, Aramaki H, Yamauchi YS, Kurata T. Detection of herpes simplex and Epstein-Barr viruses in patient with acute tonsillitis. Abstracts III International Symposium on Tonsils. Sapporo Japan; 1995 p.31.

20. Khabie N, Athanasia S, Kasperbauer JL, Mcgovern R, Gostout B, Strome S. Epstein-Barr Virus DNA ins not increased in tonsillar carcinoma. Laryngoscope 111 2001;811-4. 